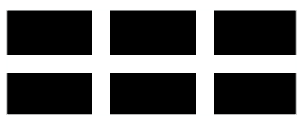

ThE WiLliam DAVIDSON INSTITUTE AT THE UNIVERSITY OF MICHIGAN BUSINESS SCHOOL

Exchange Rate Regimes, Foreign Exchange Volatility and Export Performance in Central and Eastern Europe: Just Another Blur Project?

By: Balázs Égert and Amalia Morales-Zumaquero

William Davidson Institute Working Paper Number 782

July 2005 


\title{
Exchange Rate Regimes, Foreign Exchange Volatility and Export Performance in Central and Eastern Europe: Just Another Blur Project? ${ }^{\dagger}$
}

\author{
Balázs Égert ${ }^{\ddagger} \quad$ Amalia Morales-Zumaquero*
}

\begin{abstract}
This paper attempts to analyze the direct impact of exchange rate volatility on the export performance of ten Central and Eastern European transition economies as well as its indirect impact via changes in exchange rate regimes. Not only aggregate but also bilateral and sectoral export flows are studied. To this end, we first analyze shifts in exchange rate volatility linked to changes in the exchange rate regimes and second, use these changes to construct dummy variables we include in our export function. The results suggest that the size and the direction of the impact of forex volatility and of regime changes on exports vary considerably across sectors and countries and that they may be related to specific periods.
\end{abstract}

JEL: F31

Keywords: exchange rate volatility, export, trade, transition, structural breaks

$\dagger$ The paper benefited from discussion at seminars at BOFIT and at the WIIW. We particularly thank Ian Babetskii, Iikka Korhonen and Julia Wörz for their useful remarks and suggestions. Part of the paper was written when Égert was visiting BOFIT in 2004 and 2005. The opinions expressed in the paper are those of the authors and do not necessarily represent the views of the Oesterreichische Nationalbank or the European System of Central Banks (ESCB).

$\ddagger$ Oesterreichische Nationalbank; MODEM, University of Paris X-Nanterre and William Davidson Institute. E-mail: balazs.egert@oenb.at and begert@u-paris10.fr

* University of Málaga and Centro de Estudios Andaluces, E-mail: amalia@uma.es 


\section{Introduction}

The relationship between exchange rate volatility and export flows has been studied in a large number of theoretical and empirical papers. From a theoretical point of view, the effect of exchange rate volatility on international trade is not unambiguous. On the one hand, it may be argued that a rise in exchange rate volatility increases the uncertainty of profits on contracts denominated in a foreign currency because this risk leads risk-averse and risk-neutral agents to redirect their activity from higher risk foreign markets to the lower risk home market. On the other hand, higher exchange rate volatility and thus higher risk represents greater opportunity for profit and might increase trade. ${ }^{1}$

From an empirical point of view, the large body of literature focusing on developed countries generally cannot establish any clear and statistically significant link between exchange rate volatility and aggregate or bilateral export flows. Nonetheless, differentiating between sectors yields more encouraging results even though the evidence from sectoral data suggests that the impact of volatility differs both in magnitude and direction across sectors (Klein, 1990; Bini-Smaghi, 1991; McKenzie, 1998, among others). Interestingly, Fontaigné and Freudenberg (1999) show that exchange rate volatility has a negative impact on intraindustry trade.

More recently, Doroodian (1999), Chou (2000), Achy and Sekkat (2001), Siregar and Rajan (2002), Arize et al. (2004) and Baak (2004) put pen to paper to investigate the case of less developed countries employing multilateral, bilateral and sectoral export data. Generally speaking, these papers unanimously support the hypothesis that exchange rate volatility has a negative effect on exports flows. In other words, an increase in volatility appears to depress exports in less developed countries. Along these lines, a related question very few researchers have investigated is whether changes in exchange rate regimes which can be associated with a shift in the amplitude of volatility cause export flows to decrease (see Fountas and Aristotelous, 1999, for the Exchange Rate Mechanism period and Aristotelous, 2001, for Britain and the U.S.A. from 1889 to 1999$){ }^{2}$

1 See McKenzie (1999) for a very complete survey on this topic.

2 Gravity models offer an alternative to aggregate export functions because they analyze all possible bilateral trade relations for a given set of countries (for instance, a panel of ten countries would comprise 120 bilateral trade series). The impact of forex volatility on trade is not less controversial in the gravity context: a negative relationship is found in Rose (2000), 
In this paper, we undertake to dissect the relationship between exchange rate volatility, exchange rate regimes and export performance in ten transition economies in Central and Eastern Europe (CEE), namely Bulgaria, Croatia, the Czech Republic, Hungary, Poland, Romania, Russia, Slovakia, Slovenia and Ukraine. To address this issue, we look not only at yearly and monthly aggregate export data but also analyze export flows to the European Union (EU) and at the sectoral level.

The methodological framework used here marks a departure from the traditional literature on the impact of exchange rate volatility on export flows. We proceed in three stages. First, we identify changes in exchange rate volatility using two procedures, the Iterated Cumulative Sums of Squares (ICSS) algorithm developed by Inclán and Tiao (1994) and Hansen’s (1997) approximation to the pvalues of the supreme, exponential and average statistics developed by Andrews (1993) and Andrews and Ploberger (1994). Second, we match shifts in exchange rate volatility with changes in the exchange rate regime and construct dummy variables corresponding to changes in exchange rate regimes in line with the detected structural breaks. Third, we include the indirect forex volatility measure (dummies) and, alternatively, a direct measure of exchange rate volatility (as in the previous literature) in export functions using both panel and time series cointegration estimation techniques.

The issue of forex volatility and trade, which to our knowledge has not yet been analyzed for this group of countries, is of particular interest because five countries from our pool joined the EU in May 2004 and the accession to the EU of three others is in all likelihood only a matter of time. Joining the EU entails the prospect of adopting the euro or even the obligation to do so, with the timing of this step having recently been subject to lively academic and policy discussions. If exchange rate volatility were to impede export flows, commonly perceived as the engine of economic growth in those countries, their motivations for adopting the euro and hence for making a greater effort to meet the Maastricht convergence criteria - in particular those applying to public finances - should increase considerably.

The remainder of this paper is structured as follows. Section 2 gives a detailed overview on the tested export equations, including a volatility measure, the econometric techniques for testing strucTaglioni (2002), Babetskaia-Kukharchuk and Maurel (2004) and Frankel and Rose (2004), no connection between forex volatility and trade is detected in Tenreyro (2003), and the relationship is positive in Babetskii et al. (2003) and in Bussière et al. (2004). 
tural breaks in exchange rate volatility, and the cointegration techniques used to estimate the export functions. This is followed by the discussion of the shifts in exchange rate regimes in section 3 . Section 4 reports the estimation results of the export functions based on panel and time series data and discusses the results. Section 5, finally, provides some concluding remarks.

\section{Estimation and Data Issues}

\subsection{Nominal and Real Export Functions}

Although the selection of the correct trade equation in general and that of an export equation in particular is problematic, we follow the approach employed, for instance, in McKenzie (1998), who analyzes the relationship between exchange rate volatility and trade flows in a very meticulous and systematic way. The export functions are estimated both in nominal and real terms, and include domestic and foreign income $\left(Y_{t}\right.$ and $\left.Y_{t}^{*}\right)$, relative prices $\left(P_{t}\right.$ and $\left.P_{t}^{*}\right)$, usually defined as export prices in the domestic economy to import prices in the foreign economy, the nominal exchange rate $\left(E_{t}\right)$ for nominal exports $\left(X_{t}^{N}\right)$, the real exchange rate $\left(Q_{t}=E_{t} \cdot P_{t}^{*} / P_{t}\right)$ for real exports $\left(X_{t}^{R}\right)$, and a volatility measure of the nominal and the real exchange rates, denoted by $V O L_{t}^{E}$ and $V O L_{t}^{Q}$, respectively.

It is a well-established fact in the literature dealing with transition economies that an increase in the transition economies' export flows was substantially influenced by the massive inflow of foreign direct investment (FDI) into the manufacturing sector. FDI, absorbed either by privatization or by the establishment of greenfield projects, built up substantial exports capacities in the transition economies (see Barrell and Holland, 2000; Campos and Kinoshita, 2002; or Benáček et al., 2003). Table 1 shows the dramatic increase in FDI stocks relative to GDP; by 2003, the figures are close to or well over $30 \%$ in Bulgaria, Croatia, the Czech Republic, Hungary, Poland and Slovakia. Changes of exports as a share in GDP are reported in table 2; they more than doubled in most of the countries. Hence, we modified equations of the standard specification by taking account of the prominent role of FDI in export performance:

$$
X_{t}^{N}=f\left(Y_{t}^{N}, Y_{t}^{N *}, P_{t}, P_{t}^{*}, E_{t}, F D I_{t}, V O L_{t}^{E}\right)
$$




$$
X_{t}^{R}=f\left(Y_{t}^{R}, Y_{t}^{R *}, Q_{t}, F D I_{t}, V O L_{t}^{R}\right)
$$

Economic theory suggests that the impact of nominal and real income should be positive on nominal and real exports, respectively. Moreover, an exchange rate depreciation may increase exports and the impact of domestic (foreign) relative prices on exports should be negative (positive). The volatility measure, $V O L_{t}$, is a standard direct measure of volatility, and, alternatively, a dummy variable constructed in accordance with changes in the exchange rate regime and exchange rate volatility. The effect of exchange rate volatility on exports is, from the theoretical viewpoint, ambiguous and may have a positive or negative impact on export flows.

An increase or decrease in exchange rate volatility may impact on exports with a certain delay, given that export contracts may be fixed one or two periods ahead. The same may apply to foreign direct investment, as the fruits of FDI inflows may be felt only with some delay. FDI has been mainly related either to privatization or to greenfield investments. In both cases, some time is needed to restructure the company or to build the plant, which can then produce goods for exports. This is the reason both volatility measures and FDI are used also with a lag of one or two years in equations (1) and (2).

\subsection{Testing for Structural Breaks}

The methodology used in this study to detect structural breaks in the variance of the exchange rate series is based on two procedures: the Iterated Cumulative Sums of Squares (ICSS) algorithm developed by Inclán and Tiao (1994) and Hansen's (1997) approximation to the p-values of the supreme, exponential and average statistics developed by Andrews (1993) and Andrews and Ploberger (1994).

Inclán and Tiao (1994) propose a cumulative sums of squares algorithm to estimate the number of changes in variance and the point in time of each variance shift. Let

$$
C_{k}=\sum_{t=1}^{k} \epsilon_{t}^{2}, \quad k=1, \ldots, n
$$

be the cumulative sum of the squared observations from the start to the kth point in time where $\mathrm{n}$ is 
the number of observations and denotes a series of independent observations from a normal distribution with zero mean and with unconditional variance. From equation (5), Inclán and Tiao (1994) propose to use the statistic given by:

$$
I T=\sup _{k} \sqrt{n / 2}\left|D_{k}\right|
$$

where $D_{k}=\frac{C_{k}}{C_{n}}-\frac{k}{n}$. Under the null hypothesis of constant unconditional variance, asymptotically $D_{k}$ behaves as a Brownian bridge. The critical value of 1.36 is the 95 th percentile of the asymptotic distribution of $\sup _{k} \sqrt{n / 2}\left|D_{k}\right|$. Thus, upper and lower boundaries can be set at \pm 1.36 in the $D_{k}$ plot. Exceeding these boundaries marks a significant change in the variance of the series. If the series under study has multiple break points, the $D_{k}$ function alone is not enough because of the masking effects. To avoid this problem, Inclán and Tiao (1994) design an algorithm that is based on a successive evaluation of $D_{k}$ at different parts of the series, dividing consecutively after a possible change point is found.

Our second procedure to detect structural breaks in volatility is based on univariate autoregressive models for first differences (growth rates) of the series, which we denote as qt. Following McConnell and Pérez-Quirós (2000) and Camacho (2004), we compute, at any quarter t, the Generalized Method of Moments (GMM) estimates of the specification:

$$
\begin{aligned}
q_{t} & =\mu+\phi q_{t-1}+\epsilon_{1 s} \\
\sqrt{\frac{\pi}{2}}\left|\hat{\epsilon}_{1 s}\right| & =\alpha_{1} D_{1 s}+\alpha_{2} D_{2 s}+\epsilon_{2 s}
\end{aligned}
$$

where the dummies are $D_{1 s}=\left\{\begin{array}{l}0 \text { if } s \leq T \\ 1 \text { if } s>T\end{array}\right.$ and $D_{2 s}=\left\{\begin{array}{l}1 \text { if } s \leq T \\ 0 \text { if } s>T\end{array}\right.$, and s refers to data of the period from the beginning of the sample to $\mathrm{s}$, the instruments for each period s are a constant, $q_{t}$, $D_{1 s}$ and $D_{2 s}$, T is the estimated break point $\alpha_{1}$ and $\alpha_{2}$ and are the estimators of the standard deviation. ${ }^{3}$

$\overline{3}$ If $\varepsilon_{t}$ follows a normal distribution, $\sqrt{\frac{\pi}{2}}\left|\hat{\epsilon}_{t}\right|$ is an unbiased estimator of the standard deviation of $\varepsilon_{t}$. 
Andrews (1993) and Andrews and Ploberger (1994) develop statistics for cases similar to the previous one, where the parameter $\mathrm{T}$ appears under the alternative hypothesis but not under the null of constant conditional standard deviation $\left(\alpha_{1}=\alpha_{2}\right)$. They define the function $F_{n}(T)$ as the Wald (W), Likelihood Ratio (LR) or Lagrange Multiplier (LM) statistic of the hypothesis that $\alpha_{1}=\alpha_{2}$ for break date $\mathrm{T}$, where $\mathrm{n}$ is the number of observations. They assume that $\mathrm{T}$ lies in a range $T_{1}, T_{2} \cdot{ }^{4}$ Specifically, Andrews (1993) considers the supreme statistic:

$$
\text { SupF }=\sup _{T_{1} \leq T \leq T_{2}} F_{n}(T)
$$

where $F=W, L R$ or $L M$. Andrews and Ploberger (1994) consider the exponential and average statistics, given by the following expressions:

$$
\begin{gathered}
\operatorname{Exp} F=\ln \left(\frac{1}{T_{2}-T_{1}+1} \sum_{T=T_{1}}^{T_{2}} \exp \left(\frac{1}{2} F_{n}(T)\right)\right) \\
A v e F=\frac{1}{T_{2}-T_{1}+1} \sum_{T=T_{1}}^{T_{2}} F_{n}(T)
\end{gathered}
$$

where $\mathrm{F}=\mathrm{W}, \mathrm{LR}$ or LM. The asymptotic distributions of these statistics are nonstandard and have been obtained by Andrews (1993) and Andrews and Ploberger (1994), together with their asymptotic critical values. In this paper we apply these statistics, using the associated p-values obtained following the approximation developed by Hansen (1997). In particular, we use statistics in equations (7), (8) and (9) in a new way: we sequentially apply those tests, compute the p-values associated with the supreme, exponential and average statistics for any date, and obtain a profile of p-values. In doing so, we will have numerical and graphical information that will be used to delimit periods of stability and instability in the variance of the series.

\subsection{Estimation Methods}

The order of integration of the variables is tested using the time series unit root and stationarity statistics such as the Augmented Dickey-Fuller (ADF), the Phillips-Perron (PP), the Kwiatkowski, and others

\footnotetext{
$4 \quad$ We set $T_{1}=.15 n$ and $T_{2}=.85 n$ (see Andrews, 1993, and Andrews and Ploberger, 1994).
} 
(KPSS) and the Elliot, Rothenberg, and Stock Point Optimal (ERS) tests. Moreover, the panel unit root tests, proposed by Im et al. (2003) (IPS), is used for panel data. For the time series data, equations (1) and (2) are estimated using the dynamic ordinary least squares (DOLS) suggested by Stock and Watson (1993) and the auto-regressive distributed lag (ARDL) approach proposed by Pesaran and others (2001).

For the panel data, the cointegration tests worked out by Pedroni (1999) are used. Out of the seven panel cointegration statistics developed by Pedroni (1999), we choose those, which not only permit heterogeneity in the slope coefficients and the constant term, but also allow for heterogeneous autoregressive coefficient in the residuals. These are the non-parametric PP and rho-statistics and an ADF based t-statistic. The coefficients are estimated using fixed effect OLS.

Banerjee et al. (2004) argue that in the presence of cross-unit cointegration relationships, panel cointegration tests tend to over-reject the null of no-cointegration. In (1) and (2), the foreign income and price variables may be strongly correlated across countries. To diminish the cross-sectional bias, the ratios rather than the separate series are used for panel data.

\subsection{Data Issues}

To carry out our empirical analysis, we use two sets of data. The first set of data consists of yearly data and spans the period from 1990 to 2003. It is obtained from the Economies in Transition 2004 database of the Vienna Institute for International Economic Studies (WIIW). Following our export function specification, the domestic and foreign price indices are producer prices. Some studies use consumer prices, but these indices clearly contain elements which have little to do with the exporting sectors (such as administered or regulated prices, changes in indirect taxes and imported goods). Others use export prices for the domestic economy and import prices for the foreign economy. However, we first face a data constraint here in that export prices are available only for four countries (the Czech Republic, Hungary, Poland and Slovenia). For export prices, one may use export unit values or proper export prices. However, the dynamics of the two types of series may be rather different in practice. Another source of confusion is that the series are commonly expressed in U.S. dollar terms, which implies that the exchange rate is already included in the series, and, perhaps more importantly, that 
they are of little use when the other variables are expressed in effective terms or against the euro area. For the sake of consistency, we opted for the producer price series. Nominal exports and GDP are expressed in domestic currency units, and real exports are obtained as nominal exports deflated by producer price series. Real GDP is the cumulated series based on yearly real GDP growth rates. Nominal FDI is the cumulated FDI stock, while for the real export equation, it is constructed as the stock of FDI as a share of GDP. GDP and PPI series for the foreign economy are a weighted average of euro area and U.S. series, where the weight for the euro area corresponds to the share of exports to the euro area in total exports and the weight for the U.S. series represents the rest of total exports.

A sectoral decomposition for exports is available for all countries except Russia and Ukraine; according to this decomposition, exports are classified in nine sectors. ${ }^{5}$ Table 1 indicates that most of the eight CEE economies' exports concentrate on manufacturing, representing a share of slightly more than $60 \%$ for Bulgaria and Croatia at the lower end and above $80 \%$ for the Czech Republic, Hungary and Slovakia at the higher end. The share of machinery and transport equipment alone reaches $50 \%$ in the Czech Republic and Slovakia and 60\% in Hungary in 2003.

5 (1) Food and live animals, (2) beverages and tobacco, (3) crude materials, inedible, except fuels, (4) mineral fuels, lubricants, etc., (5) animal and vegetable oils, fats, waxes, (6) chemicals and related products, (7) manufactured goods class by materials, (8) machinery and transport equipment, and (9) miscellaneous manufactured articles. 
Table 1. The Share of Exports by Sectors in Total Exports, (\%), 2003

\begin{tabular}{llllllllllc}
\hline \hline & S1 & S2 & S3 & S4 & S5 & S6 & S7 & S8 & S9 & S7+S8+S9 \\
\hline Bulgaria & 6.7 & 2.1 & 6.3 & 8.4 & 0.2 & 9.0 & 24.7 & 13.0 & 28.8 & 66.5 \\
Croatia & 9.1 & 2.6 & 5.7 & 9.6 & 0.2 & 9.6 & 14.0 & 29.4 & 19.6 & 63.0 \\
Czech Rep. & 2.7 & 0.6 & 2.8 & 2.9 & 0.1 & 5.9 & 23.1 & 50.1 & 11.8 & 85.0 \\
Hungary & 6.2 & 0.3 & 1.8 & 1.6 & 0.2 & 6.9 & 10.3 & 61.1 & 10.6 & 82.0 \\
Poland & 7.6 & 0.3 & 2.6 & 4.3 & 0.0 & 6.5 & 23.7 & 37.8 & 17.1 & 78.6 \\
Romania & 2.2 & 0.2 & 6.2 & 6.5 & 0.2 & 4.8 & 19.3 & 21.5 & 38.9 & 79.7 \\
Slovakia & 2.5 & 0.4 & 2.5 & 5.2 & 0.1 & 5.2 & 23.7 & 47.4 & 13.0 & 84.1 \\
Slovenia & 2.1 & 1.3 & 1.7 & 1.4 & 0.1 & 13.8 & 25.6 & 36.6 & 17.5 & 79.7 \\
\hline \hline
\end{tabular}

Source: Calculated on the basis of WIIW Countries in Transition 2004.

Notes: S1: Food and live animals, S2: Beverages and tobacco, S3: Crude materials, inedible, except fuels, S4: Mineral fuels, lubricants, etc.,

S5: Animal and vegetable oils, fats, waxes, S6: Chemicals and related products, S7: Manufactured goods class. by materials,

S8: Machinery and transport equipment, S9: Miscellaneous manufactured articles.

The exchange rate series are defined as units of domestic currency units per one unit of the foreign currency. Hence, a decrease (increase) in the exchange rate indicates an appreciation (depreciation). Furthermore, the real exchange rate is calculated using producer price series rather than consumer price series for reasons developed earlier.

The second set of data contains monthly data drawn mostly from the WIIW monthly database on Eastern Europe. It covers the period from January 1993 to September 2004 for the Czech Republic, Hungary, Poland and Romania, and from January 1994 to September 2004 for Croatia, Russia, Slovakia and Slovenia. For Bulgaria and Ukraine, monthly time series for exports start only in 1999 and 1998, respectively; for this reason, they are excluded from the cointegration analysis. If not indicated otherwise, the construction of the series is the same as for the yearly data. Note that the monthly FDI series are obtained by linear interpolation from yearly data. For the Czech Republic, Croatia, Hungary, Poland, Romania, Slovakia and Slovenia, besides aggregate exports, exports to the euro area are also analyzed. Domestic and foreign incomes are proxied by industrial production, the only variable available at a monthly frequency which can be taken as an approximation of gross domestic product. ${ }^{6}$ Wherever the presence of seasonality is detected in the data, the series are seasonally adjusted and are

6 Alternatively, quarterly GDP series interpolated to monthly frequency could be also used. 
taken as a natural logarithm. ${ }^{7}$

A final and important aspect of the data is the construction of variables capturing the volatility of the real exchange rate. For yearly data, two direct measures are used: (1) the standard deviation of monthly changes in the exchange rate for the 12 months of the year (VOLE), and (2) the average of standard deviations computed for each month of the year based on monthly changes in the exchange rate for a window of 12 months (VOLA). For monthly data, a standard deviation for a 12-month window is computed for each month. In addition, dummy variables are also used with the aim of capturing changes in the exchange rate regime and forex volatility. More discussion on this issue is provided in the next section.

\section{Exchange Rate Regimes and Breaks in Volatility}

\subsection{Changes in Exchange Rate Regimes}

Table 2 presents a general overview of how exchange rate regimes changes over time in transition economies. For the CEEC-5, a gradual move from a peg toward more flexibility can be observed for all countries with the exception of Slovenia, which has maintained a de facto crawling peg until its entry into ERM II in June 2004. Both Hungary and Poland started transition using pegged regimes with discretionary adjustments and then switched to crawling peg regimes. Poland widened the fluctuation margins up to $\pm 15 \%$ in consecutive steps to cope with appreciation pressures, and then opted for a pure floating regime in 2000. Hungary maintained its tight-band crawling peg regime for a longer period and adopted a pegged regime with fluctuation margins as high as $\pm 15 \%$ in April $2001 .^{8}$ The Czech Republic and Slovakia, which had a common history until 1993, had pegged regimes until 1997 and 1998, respectively, when, after a short-lived widening of the bands in the Czech Republic, and with a brusque shift in Slovakia, they moved toward a managed float. More flexible exchange rate regimes may indeed generate more amplified movements in the nominal exchange rate, which, in turn, make

\footnotetext{
7 The U.S. Census Bureau's X12 seasonal adjustment program was used.

8 Note that formally, the crawling peg regime was abandoned in October 2001, when the rate of crawl was set to zero. However, in practice, the rate of crawl between April and October 2001 was very low and remained insignificant in terms of influencing the exchange rate because of the enlarged fluctuation bands.
} 
these countries prone to being "victims" of nominal exchange rate volatility.

An opposite tendency becomes apparent in Southeastern Europe, especially in Bulgaria, which can be best described as an abrupt shift from a managed float toward more rigidity (a currency board). The cases of Croatia and Romania are similar to that of Slovenia with long unchanged regimes. Although officially announced as a managed float, the regime Romania has been operating for the past 15 years or so is a de facto crawling peg or band, and Croatia maintained its nominal exchange rate in a very narrowly managed band from 1994 onward. ${ }^{9}$ Russia and Ukraine constitute another group of countries with cyclical changes in the exchange rate regime. Starting with a managed float, Russia pegged the ruble to the dollar in 1995 and then introduced a crawling band in 1996, which ended with the return to a managed float in the aftermath of the Russian crisis. Also entering the initial phase of transition with a managed float, Ukraine followed Russia with some delay in pegging its currency to the dollar 1997 and let the hryvna float in 2000 after an uphill struggle against constant depreciation pressures from August 1998 on, which included an increase in the fluctuation band and a shift toward more depreciation of the band.

\footnotetext{
9 Croatia, Romania and Slovenia are the three countries in our sample whose de jure and de facto regimes differ markedly.
} 
Table 2. Exchange Rate Regimes in Transition Economies from 1990 to 2005

\begin{tabular}{|c|c|c|c|c|c|c|c|c|c|c|c|c|c|c|c|c|}
\hline & 1990 & 1991 & 1992 & 1993 & 1994 & 1995 & 1996 & 1997 & 1998 & 1999 & 2000 & 2001 & 2002 & 2003 & 2004 & 2005 \\
\hline \multicolumn{17}{|c|}{ CEEC5 } \\
\hline Slovenia & $\mathrm{a}$ & $3 a(6)$ & $3 a(6)$ & $3 \mathrm{a}(6)$ & $3 a(6)$ & $3 a(6)$ & $3 a(6)$ & $3 a(6)$ & $3 a(6)$ & $3 a(6)$ & $3 a(6)$ & $3 a(6)$ & $3 a(6)$ & $3 a(6)$ & $3 \mathrm{a} / 5$ & 5 \\
\hline Hungary & 1 & 1 & 1 & 1 & 1 & $1 / 2$ & 2 & 2 & 2 & 2 & 2 & $2 / 4 / 5$ & 5 & 5 & 5 & 5 \\
\hline Poland & 1 & 1 & 2 & 2 & 2 & 4 & 4 & 4 & 4 & 4 & $4 / 7$ & 7 & 7 & 7 & 7 & 7 \\
\hline Slovakia & 1 & 1 & 1 & 1 & 1 & 1 & 5 & 5 & $5 / 6$ & 6 & 6 & 6 & 6 & 6 & 6 & 6 \\
\hline CzechR. & 1 & 1 & 1 & 1 & 1 & 1 & 5 & $5 / 6$ & 6 & 6 & 6 & 6 & 6 & 6 & 6 & 6 \\
\hline \multicolumn{17}{|c|}{ Southeastern Europe } \\
\hline Bulgaria & 1 & 6 & 6 & 6 & 6 & 6 & 6 & 0 & 0 & 0 & 0 & 0 & 0 & 0 & 0 & 0 \\
\hline Croatia & & & 1 & $5(6)$ & $5(6)$ & $5(6)$ & $5(6)$ & $5(6)$ & $5(6)$ & $5(6)$ & $5(6)$ & $5(6)$ & $5(6)$ & $5(6)$ & $5(6)$ & $5(6)$ \\
\hline Romania & 1 & $3 \mathrm{~b}(6)$ & $3 \mathrm{~b}(6)$ & $3 b(6)$ & $3 \mathrm{~b}(6)$ & $3 b(6)$ & $3 b(6)$ & $3 b(6)$ & $3 b(6)$ & $3 \mathrm{~b}(6)$ & $3 b(6)$ & $3 b(6)$ & $3 \mathrm{~b}(6)$ & $3 b(6)$ & $3 b(6)$ & $3 \mathrm{~b}(6)$ \\
\hline \multicolumn{17}{|c|}{ CIS } \\
\hline Russia & & & 6 & 6 & 6 & $6 / 5$ & 4 & 4 & $4 / 6$ & 6 & 6 & 6 & 6 & 6 & 6 & 6 \\
\hline Ukraine & & & & & 6 & 6 & 6 & $6 / 5$ & 5 & 5 & $5 / 6$ & 6 & 6 & 6 & 6 & 6 \\
\hline
\end{tabular}

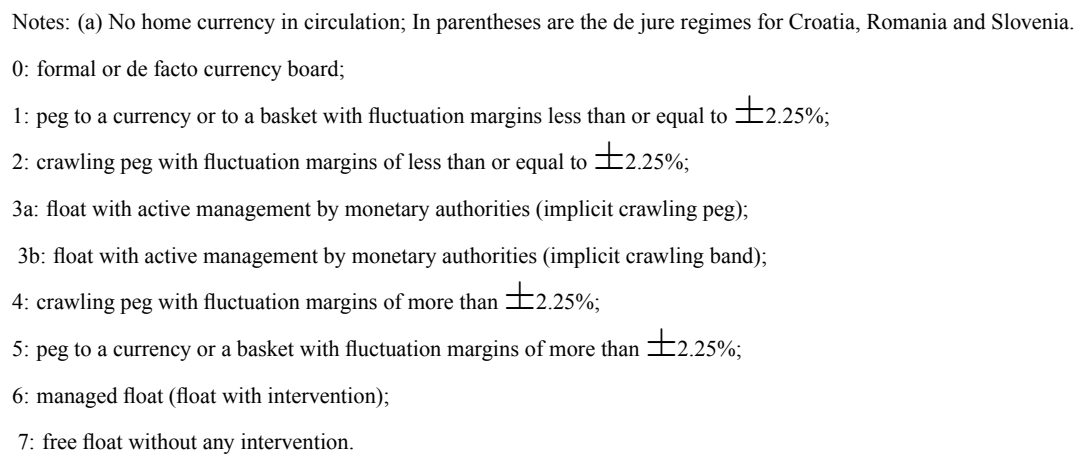

\subsection{Breaks in Volatility}

Table 3 reports the breaks in volatility detected when using the ICSS and the Hansen methods for real and nominal exchange rates in effective terms. ${ }^{10}$ Note that results are reported only for the effective exchange rate for Russia and Ukraine. A number of general observations can be made: First and perhaps most importantly, the reported results reflect most of the changes in the exchange rate regimes. Nonetheless, there is ample evidence that changes in nominal and real exchange rate volatility also occurred within one and the same exchange rate regime. Second, the two procedures (ICSS and

10 Results for the euro exchange rates are not reported because they are mostly in line with the results for the real effective exchange rates. 
Hansen) may yield different results. The ICSS procedure produces one-off changes in volatility, while the Hansen method shows the periods during which volatility in the exchange rate is different from that in the remaining observations. Generally speaking, the number of reported breaks in volatility is usually higher for the Hansen procedure than for the ICSS procedure. Third, breakpoints in the real exchange rate may or may not corroborate with breakpoints in the nominal exchange rate. Finally, the use of effective exchange rate series obtained from different sources for Hungary (Magyar Nemzeti Bank versus WIIW) may lead to differences in the results. This may be partly traced to the different time period over which the time series are available. 
Table 3. Structural Changes in Exchange Rate Volatility

\begin{tabular}{|c|c|c|c|}
\hline & & REER & NEER \\
\hline \multirow[t]{2}{*}{ Bulgaria } & ICSS & $1993.9,1994.4,1996.3,1997.5,1999.7$ & $1994.2,1996.4,1997.1,1998.10$ \\
\hline & Hansen & $\begin{array}{l}1997.2^{* *}, 1997.3^{*}, 1997.4-1998.3^{* *}, 1999.5- \\
1999.7^{* *}, 1999.9-2000.12^{* *}, 2001.1-2004.9^{*}\end{array}$ & $\begin{array}{l}\text { 1995.12-1996.4**, } 1997.2-1997.12^{* *}, \quad 1998- \\
\text { 2004.12* }\end{array}$ \\
\hline \multirow[t]{2}{*}{ Croatia } & ICSS & No breaks & No breaks \\
\hline & Hansen & No breaks & $1995.1-1995.6^{*}$ \\
\hline \multirow[t]{2}{*}{ CzechR. } & ICSS & No breaks & $1996.4,1999.2$ \\
\hline & Hansen & $\begin{array}{l}1997.12-1998.2^{* *}, 1998.3^{*}, 1998.4^{* *}, 1998.5- \\
2004.9^{*}\end{array}$ & $\begin{array}{l}\text { 1992.1**, 1992.4-1992.5*, 1992.8-1992.10**, } \\
\text { 1992.11-1995.2*, } 1995.3-1995.5^{* *}, \quad 1995.6-\end{array}$ \\
\hline \multirow[t]{3}{*}{ Hungary } & ICSS & $1994.6,1995.3$ & 1990.11 \\
\hline & Hansen & $1992.12^{* *}, 1993.3-1993.11^{*}$ & $\begin{array}{l}1991.1^{*}, 1991.2^{* *}, 1996.5-1998.10^{*}, 1998.11- \\
1998.12^{* *}\end{array}$ \\
\hline & & MNB: $2000.11^{* *}, 2000.12^{*}, 2001.3-2001.4^{* *}$ & $\begin{array}{l}\text { MNB: 1991.1*, } 1991.2-1991.4^{* *}, \quad 1991.8^{* *}, \\
\text { 1991.11**, 1992.2-1992.3*, 1996.8-1996.10**' } \\
\text { 1996.11-1998.10*, 1998.11**, 1998.12**, } \\
\text { 1999.1-1999.4**, 1999.8-2001.3**, 2001.4*, } \\
\text { 2001.5** }\end{array}$ \\
\hline \multirow[t]{2}{*}{ Poland } & ICSS & $1993.5,1997.9$ & $1993.7,1997.5$ \\
\hline & Hansen & $2002.5-2002.9^{* *}, 2003.3-2003.10^{* *}, 2004.3^{* *}$ & $\begin{array}{l}\text { 1994.1-1994.2*, 1994.3-1994.4**, 1994.5- } \\
\text { 1995.2, 1995.3-1995.4**, 1999.7-2000.3**, } \\
\text { 2000.4-2004.9* }\end{array}$ \\
\hline \multirow[t]{4}{*}{ Romania } & ICSS & $1992.10, \quad 1994.4, \quad 1995.9, \quad 1996.11, \quad 1997.2$, & $1992.6,1993.12,1997.3$ \\
\hline & & 1999.5 & \\
\hline & Hansen & $1994.3-1994.8^{* *}, \quad 1994.9-1997.2^{*}, \quad$ 1997.3- & $1992.3-2004.9^{*}$ \\
\hline & & $1998.6^{* *}, 1998.7-2004.8^{*}$ & \\
\hline \multirow[t]{2}{*}{ Slovakia } & ICSS & $1993.6,1994.6$ & $1993.7,1998.8,2000.10$ \\
\hline & Hansen & No breaks & $\begin{array}{l}1994.1-1994.2^{*}, \quad 1994.3-1995.2^{* *}, \quad 2000.3 * *, \\
2000.5-2000.9^{* *}, 2000.10-2004.9^{*}\end{array}$ \\
\hline \multirow[t]{2}{*}{ Slovenia } & ICSS & 1995.3 & 1995.2 \\
\hline & Hansen & $\begin{array}{l}1997.12-1998.8^{* *}, 1999.3-2000.5^{* *}, 2003.4^{* *}, \\
2004.7-2004.9^{* *}\end{array}$ & $\begin{array}{l}\text { 1997.4-1997.8**, } 1997.12-1998.6^{* *}, \quad 1998.7- \\
1998.8^{*}, 1998.9-1999.8^{* *}, 1999.9^{*}, 1999.10^{* *}, \\
1999.12-2000.5^{* *}, \quad 2000.8^{* *}, 2000.11^{* *}, \\
2001.5-2001.7^{* *}, \\
2002.2-2004.9^{* *},\end{array}$ \\
\hline \multirow[t]{5}{*}{ Russia } & ICSS & $1996.7,1998.6,1998.11$ & $1996.7,1998.7,1998.11$ \\
\hline & Hansen & 1995.1-1995.2*, 1995.3**, 1995.4*, 1995.5**, & $1998.12^{* *}, 2001.11-2002.2^{* *}, 2002.3-2004.9^{*}$ \\
\hline & & $1996.3-1996.5^{* *}, \quad 1996.6^{*}, \quad 1996.6^{*}, \quad 1998.1-$ & \\
\hline & & $1998.7^{* *}, \quad 2002.1-2002.5^{* *}, 2002.6-2003.11^{*}$ & \\
\hline & & 2003.12- $2004.9^{* *}$ & \\
\hline \multirow[t]{2}{*}{ Ukraine } & ICSS & $1998.7,1998.9,2000.3$ & $1998.7,1998.9,1999.12$ \\
\hline & Hansen & $2003.3^{* *}$ & 2001.9-2002.2**, 2002.3-2004.9* \\
\hline
\end{tabular}

Notes: REER and NEER refer to the real effective exchange rate and the nominal effective exchange rate. The exchange rate series are obtained from the WIIW monthly database and are PPI-based real exchange rates. MNB refers to the exchange rate series provided by the National Bank of Hungary. * and ** indicate evidence for instability at the $5 \%$ and $10 \%$ significant levels, respectively. 


\subsection{The Construction of Dummy Variables}

The dummy variables take the value 0 for the low volatility regime and 1 for the high volatility regime. Table 4 below summarizes the periods for which the dummy variables are constructed along the line of changes in the exchange rate regimes combined with the changes in forex volatility analyzed previously and shows the periods for which the dummy variables take the value 1. For yearly data, only one high volatility regime is used, mainly because of the difficulty of combining several alternative volatility regimes for given countries. ${ }^{11}$ This gap is filled for monthly data, where several alternative periods are considered for the Czech Republic, Hungary, Poland, Slovakia and Russia. For Croatia, Romania and Slovenia, only the direct volatility measures are employed in the absence of changes in the exchange rate regime. For Croatia, the identified high volatility regime from 1990 to 1993 cannot be tested for monthly data, as they start only in 1994. As noted earlier, estimations are not carried out on a monthly basis for Bulgaria and Ukraine.

Table 4. Dummy Variables and High Volatility Regimes

\begin{tabular}{llll}
\hline \hline & Yearly data & Monthly data \\
\hline Bulgaria & $1991-1996$ & & High \\
\hline Croatia & $1990-1993$ & & Not available \\
\hline Czech R. & $1997-2003$ & DUM1 & $1997.5-2004.9$ \\
& & DUM2 & $1998.5-2004.9$ \\
\hline Hungary & $1990-1994 ; 2001-2003$ & DUM1 & $1995.3-2004.9$ \\
& & DUM2 & $2001.4-2004.9$ \\
\hline Poland & $1990-1991 ; 1995-2003$ & DUM1 & $1998.10-2004.9$ \\
& & DUM2 & $2000.3-2004.9$ \\
\hline Romania & - & & - \\
\hline Slovakia & $1998-2003$ & DUM1 & $1997.1-2004.9$ \\
& & DUM2 & $1998.10-2004.9$ \\
\hline Slovenia & - & & - \\
\hline Russia & $1990-1994 ; 1998-2003$ & DUM1 & $1994.1-1997.6$ \\
& & DUM2 & $1998.9-2004.9$ \\
\hline Ukraine & $1990-1996 ; 1999-2003$ & & Not available \\
\hline \hline
\end{tabular}

\footnotetext{
11 It should be noted that the period over which yearly data are available is sometimes longer than the one readily available for monthly data. This is the case, for instance, for Croatia, where large devaluations occurred from 1990 to 1993 ; this is why we constructed a dummy to cover this period.
} 


\section{Estimation Results for Panel Data}

We start by analyzing the impact of exchange rate volatility and changes in exchange rate regimes on export performance in a panel context. The panel unit root tests indicate that most of the variables are I(1). The two direct volatility measures are exceptions. With this as a background, panel cointegration is used for level variables including the dummy variables, and fixed effect OLS is applied to data in first differences. In the first difference specification, the volatility measures are not first-difference, given the fact that they are already stationary in levels.

The Pedroni mean group statistics reported in Table 5 show the presence of cointegration for most of the specifications. Table $6 \mathrm{a}$ contains the estimation results including the volatility measure and FDI with a lag of one year. When all ten countries are included in the panel (CEEC-10), the indirect dummy volatility measure turns out to have a positive sign for the level equations (shaded), indicating that an increase in exchange rate volatility is associated with an increase in exports. For the equations in first differences, all (lagged) volatility measures are mostly insignificant. This result implies that an increase in exchange rate volatility causes exports to decrease with a delay. Nonetheless, results for the CEEC8 (excluding Russia and Ukraine) indicate that the direct volatility measures (VOLE and VOLA) are statistically significant with a negative sign - for both the nominal and real export equations. These results are fairly robust to the time period investigated, as the results for the period 1993 to 2003 are very similar to those obtained for 1990 to 2003 and 1995 to 2003.

For sectoral exports, it appears that the exchange rate volatility measures are not significant for the first five sectors ${ }^{12}$ (and are therefore not reported here). By contrast, as shown in Table 6b, exchange rate volatility is found to hamper manufacturing exports. This does not mean that these sectors were the only ones to be affected. Exports of the chemicals sector are in fact also influenced by exchange rate volatility. Although the effect is mostly positive for the cointegration relationships including the dummy variables, the effect switches sign when data in first differences are used: higher exchange rate volatility appears to dampen export growth in chemicals and manufacturing. These results seem to be

12 (1) Food and live animals, (2) beverages and tobacco, (3) crude materials, inedible, except fuels, (4) mineral fuels, lubricants and (5) animal and vegetable oils, fats, waxes. 
most robust for manufactured goods classed by materials and for machinery and transport equipment.

Table 5. Group Mean Pedroni Panel Cointegration Tests from 1993 to 2003

\begin{tabular}{|c|c|c|c|c|c|c|c|}
\hline & & \multicolumn{3}{|c|}{ Nominal Exports } & \multicolumn{3}{|c|}{ Real Exports } \\
\hline & & rho-stat & pp-stat & adf-stat & rho-stat & pp-stat & adf-stat \\
\hline CEEC10 & Total Exports & 2.994 & $-10.012 * * *$ & $-5.267^{* * *}$ & 3.187 & $-2.259^{* *}$ & -1.262 \\
\hline \multirow[t]{5}{*}{ CEEC8 } & Total Exports & 2.767 & $-8.698 * * *$ & $-4.003 * * *$ & 2.713 & $-2.856^{* *}$ & -1.295 \\
\hline & Sector 6 & 3.136 & $-3.470 * * *$ & $-1.836^{*}$ & 2.165 & $-5.484 * * *$ & $-3.349^{* * *}$ \\
\hline & Sector 7 & 2.595 & $-7.989^{* * *}$ & $-6.501^{* * *}$ & 1.830 & $-7.481^{* * *}$ & $-4.829^{* * *}$ \\
\hline & Sector 8 & 2.879 & $-7.364 * * *$ & $-3.544 * * *$ & 2.347 & $-5.326^{* * *}$ & $-3.054^{* * *}$ \\
\hline & Sector 9 & 2.912 & $-4.819^{* * *}$ & $-4.637^{* * *}$ & 2.786 & -0.929 & -0.486 \\
\hline
\end{tabular}

Notes: *,** and $* * *$ indicate that the null of no cointegration is rejected at the $10 \%, 5 \%$ and $1 \%$ level, respectively.

Table 6a. Aggregate Exports: Coefficient Estimates from 1993 to 2003

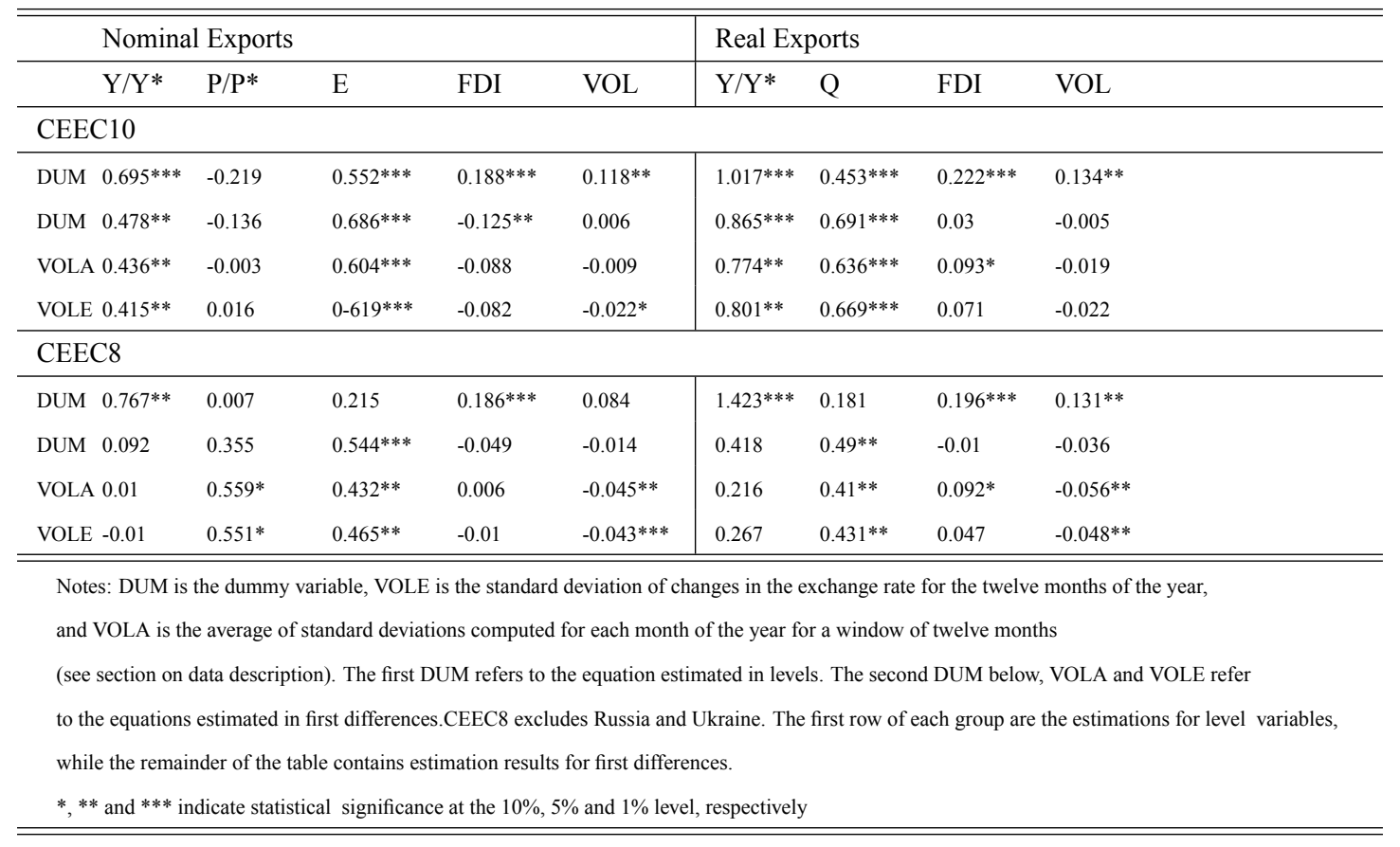


Table 6b. Sectoral Exports: Coefficient Estimates from 1993 to 2003

\begin{tabular}{|c|c|c|c|c|c|c|c|c|c|}
\hline \multicolumn{6}{|c|}{ Nominal Exports } & \multicolumn{4}{|c|}{ Real Exports } \\
\hline & $\mathrm{Y} / \mathrm{Y}^{*}$ & $\mathrm{P} / \mathrm{P}^{*}$ & $\mathrm{E}$ & FDI & VOL & $\mathrm{Y} / \mathrm{Y}^{*}$ & Q & FDI & VOL \\
\hline \multicolumn{10}{|c|}{ CEEC8-Chemicals and Related Products (Sector 6) } \\
\hline DUM & $1.915^{* * *}$ & $-1.706^{* * *}$ & $0.919 * *$ & -0.008 & 0.068 & $1.82^{* * *}$ & $0.714^{* *}$ & $0.052^{* *}$ & $0.105^{*}$ \\
\hline DUM & $0.832^{*}$ & -0.628 & $0.862 * *$ & -0.035 & 0.021 & $1.26^{* *}$ & $0.655^{* *}$ & 0.024 & 0.033 \\
\hline VOLA & 0.685 & -0.349 & $0.751 * *$ & 0.019 & -0.051 & 0.86 & $0.736^{* *}$ & 0.147 & -0.049 \\
\hline VOLE & 0.635 & -0.311 & $0.773^{* *}$ & 0.009 & $-0.058^{*}$ & 0.658 & $0.683^{* *}$ & 0.147 & $-0.065^{*}$ \\
\hline \multicolumn{10}{|c|}{ CEEC8-Manufactured Goods Class by Materials (Sector 7) } \\
\hline DUM & $0.902 * * *$ & -0.374 & $0.494^{*}$ & $0.115^{* * *}$ & 0.041 & $1.16^{* * *}$ & $0.454^{* *}$ & $0.133^{* * *}$ & $0.081^{* *}$ \\
\hline DUM & 0.107 & 0.493 & $0.436^{* *}$ & -0.006 & 0.018 & 0.281 & $0.333^{*}$ & 0.037 & 0.006 \\
\hline VOLA & -0.024 & $0.742 *$ & 0.337 & 0.043 & $-0.046^{* *}$ & -0.026 & 0.29 & $0.135^{* *}$ & $-0.054^{*}$ \\
\hline VOLE & -0.017 & 0.686 & $0.386^{*}$ & 0.019 & $-0.034^{* *}$ & 0.084 & 0.292 & 0.082 & -0.035 \\
\hline \multicolumn{10}{|c|}{ CEEC8-Machinery and Transport Equipment (Sector 8) } \\
\hline DUM & 0.899 & -0.186 & 0.143 & $0.367 * * *$ & 0.113 & $2.641 * * *$ & 0.35 & $0.354^{* * *}$ & $0.226^{* *}$ \\
\hline DUM & -0.134 & 0.748 & 0.314 & $-0.192 *$ & -0.092 & -0.203 & 0.219 & -0.108 & $-0.121^{* *}$ \\
\hline VOLA & -0.166 & 0.991 & 0.101 & -0.088 & $-0.073^{* *}$ & -0.296 & 0.079 & 0.064 & $-0.108^{* *}$ \\
\hline VOLE & -0.193 & 0.969 & 0.157 & -0.115 & $-0.067^{* *}$ & -0.432 & 0.086 & 0.028 & $-0.112^{* *}$ \\
\hline \multicolumn{10}{|c|}{ CEEC8-Miscellaneous Manufactured Articles (Sector 9) } \\
\hline DUM & 0.077 & $1.522 * * *$ & $-0.519^{*}$ & $0.166^{* * *}$ & 0.075 & 0.15 & $-0.831 * * *$ & $0.206^{* * *}$ & 0.05 \\
\hline DUM & 0.067 & 0.289 & $0.654 * * *$ & 0.038 & $-0.043^{*}$ & 0.249 & $0.653 * * *$ & $0.118^{* *}$ & $-0.104 * * *$ \\
\hline VOLA & 0.102 & 0.295 & $0.605 * * *$ & 0.062 & -0.012 & 0.381 & $0.522^{* *}$ & $0.135^{* *}$ & -0.02 \\
\hline VOLE & 0.089 & 0.307 & $0.609 * * *$ & 0.06 & -0.015 & 0.468 & $0.584^{* *}$ & 0.091 & -0.025 \\
\hline
\end{tabular}

Notes: As for Table 6a.

\section{Estimation Results for Time Series}

Estimation results resting on panel data indicate that exchange rate volatility might impact on both nominal and real exports. Given that panel results provide a general picture of the studied phenomenon, there remains an unanswered question about the role of exchange rate volatility in the individual countries. This question, which is of the utmost importance for policymakers, can be best answered by drawing on time series analysis, to which we now direct our radar and other gadgets.

With a very few exceptions, the time series are difference stationary, i.e. I(1) processes. This finding and the more than 120 monthly observations (141 for the period from January 1993 to September 2004 and 129 for the period from January 1994 to September 2004) motivate us to use cointegration to study 
to what extent, if at all, exchange rate volatility influences export performance. To check our results, we carry out OLS estimations for variables in year-on-year changes ( ) that turn out to be stationary in levels.

We separate the countries under study into two groups. One group contains countries where no changes in the exchange rate regime occurred over the time span of the monthly data, namely Croatia, Romania and Slovenia. The other group includes the remaining countries. For all countries, results for DOLS and the bounds testing approach are reported. Coefficient estimates are shown only if cointegration relationships could be established for the export equation. Results for year-on-year changes are reported systematically. Lagged values of both the volatility measures and FDI are used for panel data. The outcome of this exercise is included in the paper only if the results are markedly different from the results based on contemporaneous volatility and FDI. The estimation results are displayed in tables $7 \mathrm{a}$ to $7 \mathrm{e}$. To save space, these tables only include the coefficient estimates for the volatility measures. ${ }^{13}$

\subsection{Croatia, Romania and Slovenia}

We used only the direct volatility measure for the three countries without changes in the exchange rate regime. ${ }^{14}$ The absence of major changes in the exchange rate regime does not necessarily imply that these countries are immune to forex volatility, however. As a matter of fact, they appear to be unevenly affected by exchange rate volatility. Slovene exports do not seem to be linked to exchange rate volatility. For all specifications including real and nominal exports both in effective terms and to the euro area, the coefficient of exchange rate volatility is statistically insignificant except for the case of lagged volatility and FDI for nominal exports to the euro area. Moreover, the coefficient estimates for the rest of the variables in the model generally bear the expected signs when they are significant (except for the domestic relative price).

For Romania, it is difficult to establish cointegration for half of the cases. When cointegration is found, and if the coefficient estimate is significant at any standard significance level, volatility is negatively correlated to exports. However, this only holds for nominal exports. For year-on-year

\footnotetext{
13 The full results are available upon request from the authors.

14 Therefore, we do not construct dummies capturing nonexisting changes in the exchange rate regime.
} 
changes, a statistically significant negative relationship is found between exports and lagged forex volatility. The biggest impact of forex volatility on exports could be established for Croatia. Although mostly unimportant when volatility is used in a contemporaneous manner, volatility included with a lag of 12 months is associated negatively with exports, and this relationship appears to be particularly robust: not only are the results are very similar for nominal and real exports but they are also very comparable regardless of the estimation method used (DOLS, ARDL or year-on-year changes). ${ }^{15}$

\subsection{The Czech Republic, Hungary, Poland, Russia and Slovakia}

This section dissects the results obtained for the group of countries which experienced a number of changes in the exchange rate regime. Putting the Czech Republic under the microscope reveals that exports, especially those to the euro area, are hampered by exchange rate volatility, conditioned on the other variables included in the export functions. This result comes instantaneously without using lagged variables. What is somewhat surprising is the finding that when using the dummy variables aimed at capturing volatility increases related to regime changes, the estimated coefficients usually turn out to be positive, indicating that the shift toward a more flexible regime tends to generate more export flows. This holds true for both dummy variables, each of which captures a somewhat different time period. A possible explanation for the fact that a negative relationship could be found between the direct measure of forex volatility and exports and that the relationship is reversed for the dummies may be that exchange rate volatility during the float and, perhaps more importantly, during the period prior to the float changed.

The story for Hungary is a little bit different than for the Czech Republic. For nominal and real exports, the direct volatility measure is mostly significant and always has a positive sign. However, when volatility is considered with a lag of 12 months, the coefficients switch sign all of a sudden. This is something that we could observe for the panel estimations; it indicates the delay with which an increase in exchange rate volatility (negatively) affects export flows. Such a delay might be the result of export contracts often extending as long as up to one year. Coming to the dummy variables, it

\footnotetext{
15 The fact that the coefficient estimates, if significant, usually bear the expected sign deserves mention. For real exports, the sign on the real exchange rate is, however, negative, which indicates that an appreciation of the exchange rate is associated with an increase in exports. The sign on FDI time and again has a counterintuitive negative sign.
} 
appears that the dummy that covers the recent widening of the fluctuation bands to $\pm 15 \%$ most often has a negative sign, with or without lags. However, this observation only holds for the real export equation, as the relationship turns out to be rather insignificant for nominal exports. Regarding the dummy covering the period from 1995 to 2004, the results are conflicting in the sense that the direction of the relationship is fairly difficult to establish across the nominal and real export equations.

In Poland, we can partly observe the Hungarian story. For nominal exports, and for real exports, the effect of the lagged direct volatility measure on export flows is negative if there is a statistically significant relationship. Exactly the same applies for the first dummy spanning the period from October 1998 to September 2004: the lagged dummy always bears a negative sign. However, for the second dummy taking the value of 1 from March 2000 to September 2004, the sign is found to be consistently positive. A first explanation for this may be that exchange rate volatility generated by the widening of the fluctuation bands may have impacted negatively on exports, but after a while, poorly performing export firms dropped out, and only those which were able to cope with increased volatility remained. The second explanation is similar in spirit to the one provided for the Czech case. Over the period from 1998 to 2004, there may have been several forex volatility regimes. Thus, increased volatility took place after the widening of the bands, and volatility calmed down later on. This may have coincided with the official move toward a free float, which did not generate any additional forex volatility.

The case of Slovakia contrasts with the findings for the other countries because the direct volatility measure seems to be positively associated with exports, and this assessment remains unchallenged even when using the volatility measure with lags. Concerning the impact of the different exchange rate regimes, the situation is astonishingly similar to that observed for Poland: the dummy variable that covers the period starting in January 1997 when the fluctuation margins were widened to $\pm 7 \%$ indicates a negative relationship between the regime shift and exports. However, starting with October 1998, when a managed float was officially introduced, does alter this conclusion, as the sign becomes positive. The two explanations put forwards for Poland may also apply here.

Let us now take a closer look at Russia, for which only exports in effective terms could be examined because of the unavailability of data for exports to the euro area or the U.S. economy alone. The results 
contradict each other, as both negative and positive signs can be found even if the positive signs appear to outweigh the negative ones. The fact that no clear relationship between volatility and exports could be found is not very surprising in the light of the high share of oil-related products in total exports (amounting to about 50\% of total exports in 2003). Exports of oil-related products may be suspected to be linked more closely to the level of the (real) exchange rate than to its volatility. While for the other countries both the real exchange rate and the nominal exchange rate are correlated positively with exports, i.e. a depreciation results in an increase in exports, the results for Russia indicate the opposite to be the case, which is especially true of the real exchange rate: an appreciation of the exchange rate is linked to a rise in exports. 
Table 7a. Exchange Rate Volatility and Real Exports for the Czech Republic and Russia

\begin{tabular}{|c|c|c|c|c|c|}
\hline \multicolumn{3}{|c|}{ Czech Republic } & \multicolumn{3}{|c|}{ Russia } \\
\hline \multicolumn{6}{|c|}{ Real Exports } \\
\hline \multicolumn{6}{|c|}{ VOL } \\
\hline \multirow[t]{3}{*}{ EFF } & $\operatorname{DOLS}(0,3) \mathrm{SIC}$ & & EFF & $\operatorname{DOLS}(0,0) \operatorname{SIC}$ & \\
\hline & $\operatorname{ARDL}(1,1) \operatorname{SIC}$ & & & ARDL(1,1)HQ & $-0.052 * * *$ \\
\hline & YOY & 0.016 & & YOY & 0.004 \\
\hline \multirow[t]{3}{*}{ EUR } & $\operatorname{DOLS}(0,0) \mathrm{SIC}$ & $-0.026 * * *$ & EUR & $\operatorname{DOLS}(0,0) \mathrm{SIC}$ & $0.045^{* * *}$ \\
\hline & $\operatorname{ARDL}(1,1) \mathrm{SIC}$ & $-0.028 * *$ & VOL12 & $\operatorname{ARDL}(1,1) \mathrm{SIC}$ & $0.053 * * *$ \\
\hline & YOY & 0.005 & FDI12 & YOY & $0.044 * * *$ \\
\hline \multicolumn{6}{|c|}{ DUM1 } \\
\hline \multirow[t]{3}{*}{ EFF } & $\operatorname{DOLS}(0,0) \mathrm{SIC}$ & & $\mathrm{EFF}$ & $\operatorname{DOLS}(0,1) \mathrm{SIC}$ & \\
\hline & ARDL $(2,2)$ SIC & & & ARDL $(1,1) \mathrm{SIC}$ & 0.025 \\
\hline & YOY & $0.071 * * *$ & & YOY & $0.111 * * *$ \\
\hline \multirow[t]{3}{*}{ EUR } & DOLS(1,0)HQ & $-0.035^{* *}$ & & & \\
\hline & $\operatorname{ARDL}(1,1) \mathrm{SIC}$ & & & & \\
\hline & YOY & $0.069 * * *$ & & & \\
\hline \multicolumn{6}{|c|}{ DUM2 } \\
\hline \multirow[t]{3}{*}{ EFF } & $\operatorname{DOLS}(0,3) \operatorname{SIC}$ & & & & \\
\hline & $\operatorname{ARDL}(2,2) \mathrm{SIC}$ & & & & \\
\hline & YOY & $0.065 * * *$ & & & \\
\hline \multirow[t]{3}{*}{ EUR } & $\operatorname{DOLS}(0,0) \mathrm{SIC}$ & 0.008 & & & \\
\hline & $\operatorname{ARDL}(1,1) \mathrm{SIC}$ & & & & \\
\hline & YOY & $0.065 * * *$ & & & \\
\hline
\end{tabular}

Notes: The lag structure is shown in parentheses after DOLS and ARDL. YOY refers to the OLS estimates on year-on-year changes. VOL is the direct volatility measures, DUM1 and DUM2 are the dummies shown in Table 4. EFF indicates effective exports while EUR is exports to the Euro area

VOL12 and FDI12 show that volatility and FDI are used with a lag of 12 months. *, ** and $* * *$ indicate statistical significance at the $10 \%, 5 \%$ and $1 \%$ levels, respectively. 
Table 7b. Exchange Rate Volatility and Nominal Exports for the Czech Republic and Russia

\begin{tabular}{|c|c|c|c|c|c|}
\hline \multicolumn{3}{|c|}{ Czech Republic } & \multicolumn{3}{|c|}{ Russia } \\
\hline \multicolumn{6}{|c|}{ Nominal Exports } \\
\hline \multicolumn{6}{|c|}{ VOL } \\
\hline \multirow[t]{3}{*}{$\mathrm{EFF}$} & $\operatorname{DOLS}(0,0) \mathrm{SIC}$ & $-0.022 * *$ & $\mathrm{EFF}$ & DOLS $(4,4)$ SIC & -0.002 \\
\hline & $\operatorname{ARDL}(1,1) \mathrm{SIC}$ & -0.024 & & ARDL $(1,1) \mathrm{HQ}$ & $-0.024 * *$ \\
\hline & YOY & 0.002 & & YOY & 0.025 \\
\hline \multirow[t]{3}{*}{ EUR } & $\operatorname{DOLS}(0,0) \mathrm{SIC}$ & $-0.072 * * *$ & EUR & $\operatorname{DOLS}(0,0) \mathrm{SIC}$ & $0.042 * * *$ \\
\hline & $\operatorname{ARDL}(1,1) \mathrm{SIC}$ & & VOL12 & $\operatorname{ARDL}(1,1) \operatorname{SIC}$ & $0.043 * * *$ \\
\hline & YOY & -0.013 & FDI12 & YOY & $0.065 * * *$ \\
\hline \multicolumn{6}{|c|}{ DUM1 } \\
\hline \multirow[t]{3}{*}{$\mathrm{EFF}$} & $\operatorname{DOLS}(0,0) \mathrm{SIC}$ & $0.068 * *$ & $\mathrm{EFF}$ & $\operatorname{DOLS}(0,0) \mathrm{SIC}$ & $-0.155^{* *}$ \\
\hline & $\operatorname{ARDL}(2,2) \mathrm{SIC}$ & 0.081 & & $\operatorname{ARDL}(2,2) \mathrm{SIC}$ & \\
\hline & YOY & $0.076^{* * *}$ & & YOY & 0.043 \\
\hline \multirow[t]{3}{*}{ EUR } & $\operatorname{DOLS}(0,0) \mathrm{SIC}$ & & & & \\
\hline & $\operatorname{ARDL}(1,1) \operatorname{SIC}$ & & & & \\
\hline & YOY & $0.124 * * *$ & & & \\
\hline \multicolumn{6}{|c|}{ DUM2 } \\
\hline \multirow[t]{3}{*}{ EFF } & DOLS(3,3)HQ & $0.062 * * *$ & & & \\
\hline & ARDL(1,1)SIC & 0.058 & & & \\
\hline & YOY & $0.077^{* * *}$ & & & \\
\hline \multirow[t]{3}{*}{ EUR } & $\operatorname{DOLS}(3,4) \mathrm{AIC}$ & & & & \\
\hline & $\operatorname{ARDL}(1,1) \operatorname{SIC}$ & & & & \\
\hline & YOY & $0.182 * * *$ & & & \\
\hline
\end{tabular}


Table 7c. Exchange Rate Volatility and Real Exports for Hungary, Poland and Slovakia

\begin{tabular}{|c|c|c|c|c|c|c|c|c|}
\hline \multicolumn{3}{|c|}{ Hungary } & \multicolumn{3}{|c|}{ Poland } & \multicolumn{3}{|c|}{ Slovakia } \\
\hline \multicolumn{9}{|c|}{ Real Exports } \\
\hline \multicolumn{9}{|c|}{ VOL } \\
\hline \multirow[t]{3}{*}{ EFF } & $\operatorname{DOLS}(0,0) \operatorname{SIC}$ & $0.082 * * *$ & EFF & $\operatorname{DOLS}(0,0) \mathrm{SIC}$ & & EFF & $\operatorname{DOLS}(0,0) \mathrm{SIC}$ & $0.099^{* * *}$ \\
\hline & $\operatorname{ARDL}(4,4) \mathrm{FIX}$ & $0.116^{* * *}$ & & $\operatorname{ARDL}(1,1) \mathrm{SIC}$ & & & $\operatorname{ARDL}(1,1) \mathrm{SIC}$ & \\
\hline & YOY & $0.057 * *$ & & YOY & -0.03 & & YOY & $0.081 * * *$ \\
\hline \multirow[t]{3}{*}{ EUR } & $\operatorname{DOLS}(0,0) \mathrm{SIC}$ & & EUR & DOLS $(4,4)$ SIC & & EUR & $\operatorname{DOLS}(0,0) \mathrm{SIC}$ & $0.029 * *$ \\
\hline & $\operatorname{ARDL}(2,2) \mathrm{SIC}$ & & & $\operatorname{ARDL}(1,1) \mathrm{SIC}$ & & & $\operatorname{ARDL}(1,1) \mathrm{SIC}$ & \\
\hline & YOY & $0.079 * * *$ & & YOY & -0.045 & & & \\
\hline EFF & $\operatorname{DOLS}(0,0) \mathrm{SIC}$ & $-0.06^{* * *}$ & $\mathrm{EFF}$ & $\operatorname{DOLS}(0,2) \mathrm{HQ}$ & $-0.069^{*}$ & & & \\
\hline \multirow[t]{2}{*}{ VOL12 } & ARDL $(4,4) F I X$ & $-0.102 * *$ & VOL12 & ARDL $(1,1) \mathrm{SIC}$ & & & & \\
\hline & YOY & $-0.127 * * *$ & FDI12 & YOY & 0.029 & & & \\
\hline EUR & $\operatorname{DOLS}(0,0) \mathrm{SIC}$ & & EUR & $\operatorname{DOLS}(0,0) \mathrm{SIC}$ & & & & \\
\hline \multirow[t]{2}{*}{ VOL12 } & $\operatorname{ARDL}(2,2) \mathrm{SIC}$ & & VOL12 & ARDL $(1,1)$ SIC & & & & \\
\hline & YOY & $-0.09^{* * *}$ & FDI12 & YOY & 0.029 & & & \\
\hline
\end{tabular}

\begin{tabular}{|c|c|c|c|c|c|c|c|c|}
\hline \multicolumn{9}{|c|}{ DUM1 } \\
\hline \multirow[t]{3}{*}{ EFF } & $\operatorname{DOLS}(0,0) \mathrm{SIC}$ & $-0.074 * *$ & $\mathrm{EFF}$ & $\operatorname{DOLS}(0,0) \mathrm{SIC}$ & $0.069 * * *$ & $\mathrm{EFF}$ & $\operatorname{DOLS}(0,0) \mathrm{SIC}$ & $-0.162 * * *$ \\
\hline & $\operatorname{ARDL}(2,2) \mathrm{SIC}$ & $-0.164 * *$ & & \multicolumn{2}{|l|}{$\operatorname{ARDL}(1,1) \mathrm{SIC}$} & & \multicolumn{2}{|l|}{$\operatorname{ARDL}(1,1) \mathrm{SIC}$} \\
\hline & YOY & $0.083 * *$ & & YOY & -0.013 & & YOY & 0.066 \\
\hline \multirow[t]{3}{*}{ EUR } & $\operatorname{DOLS}(0,0)$ SIC & & EUR & \multicolumn{2}{|l|}{$\operatorname{DOLS}(1,0) \mathrm{SIC}$} & \multirow[t]{3}{*}{ EUR } & $\operatorname{DOLS}(1,0) \mathrm{SIC}$ & $-0.063 * * *$ \\
\hline & $\operatorname{ARDL}(2,2) \operatorname{SIC}$ & $-0.185^{* *}$ & & \multicolumn{2}{|l|}{$\operatorname{ARDL}(1,1) \mathrm{SIC}$} & & \multicolumn{2}{|l|}{$\operatorname{ARDL}(1,1) \mathrm{SIC}$} \\
\hline & YOY & 0.02 & & YOY & -0.004 & & YOY & 0.029 \\
\hline EUR & $\operatorname{DOLS}(4,4) \mathrm{FIX}$ & $-0.115^{* * *}$ & $\mathrm{EFF}$ & $\operatorname{DOLS}(0,2) \mathrm{HQ}$ & $-0.05^{*}$ & & & \\
\hline \multirow[t]{5}{*}{ VOL12 } & $\operatorname{ARDL}(2,2) \mathrm{SIC}$ & $-0.204 * * *$ & FDI12 & $\operatorname{ARDL}(1,1) \mathrm{SIC}$ & & & & \\
\hline & YOY & $-0.049^{*}$ & & YOY & -0.048 & & & \\
\hline & & & EUR & $\operatorname{DOLS}(0,2) \mathrm{HQ}$ & $-0.088 * * *$ & & & \\
\hline & & & FDI12 & $\operatorname{ARDL}(1,1) \mathrm{SIC}$ & & & & \\
\hline & & & & YOY & -0.04 & & & \\
\hline
\end{tabular}

\section{DUM2}

\begin{tabular}{|c|c|c|c|c|c|c|c|c|}
\hline \multirow[t]{3}{*}{ EFF } & $\operatorname{DOLS}(0,0) \mathrm{SIC}$ & -0.018 & EFF & $\operatorname{DOLS}(0,4) \mathrm{AIC}$ & $0.098 * * *$ & EFF & DOLS(1,2)AIC & $0.218^{* * *}$ \\
\hline & $\operatorname{ARDL}(4,4) \mathrm{FIX}$ & 0.013 & & ARDL $(1,1) \mathrm{SIC}$ & & & ARDL $(1,1) \mathrm{SIC}$ & \\
\hline & YOY & $0.094 * * *$ & & YOY & $0.097 * * *$ & & YOY & $0.088^{* * *}$ \\
\hline \multirow[t]{3}{*}{ EUR } & $\operatorname{DOLS}(0,0) \mathrm{SIC}$ & & EUR & $\operatorname{DOLS}(0,0)$ SIC & $0.178 * * *$ & EUR & DOLS $(0,0)$ SIC & $0.157^{* * *}$ \\
\hline & $\operatorname{ARDL}(2,2) \mathrm{SIC}$ & 0.014 & & $\operatorname{ARDL}(1,1) \mathrm{SIC}$ & & & $\operatorname{ARDL}(1,1) \mathrm{SIC}$ & \\
\hline & YOY & $0.102^{* * *}$ & & YOY & $0.088^{* * *}$ & & YOY & $0.041 * *$ \\
\hline
\end{tabular}


Table 7d. Exchange Rate Volatility and Nominal Exports for Hungary, Poland and Slovakia

\begin{tabular}{|c|c|c|c|c|c|c|c|c|}
\hline \multicolumn{3}{|c|}{ Hungary } & \multicolumn{3}{|c|}{ Poland } & \multicolumn{3}{|c|}{ Slovakia } \\
\hline \multicolumn{9}{|c|}{ Nominal Exports } \\
\hline \multirow[t]{3}{*}{ EFF } & $\operatorname{DOLS}(0,0) \operatorname{SIC}$ & $0.03 * * *$ & EFF & $\operatorname{DOLS}(0,0) \mathrm{SIC}$ & $0.097 * * *$ & EFF & $\operatorname{DOLS}(0,0) \mathrm{SIC}$ & $0.058^{* * *}$ \\
\hline & $\operatorname{ARDL}(2,2) \mathrm{SIC}$ & $0.04^{*}$ & & ARDL $(1,1)$ SIC & & & $\operatorname{ARDL}(1,1) \operatorname{SIC}$ & \\
\hline & YOY & $0.04 * * *$ & & YOY & -0.028 & & YOY & $0.14 * * *$ \\
\hline \multirow[t]{3}{*}{ EUR } & $\operatorname{DOLS}(0,0) \mathrm{SIC}$ & $0.033 * * *$ & EUR & $\operatorname{DOLS}(0,0) \mathrm{SIC}$ & $0.11 * * *$ & EUR & $\operatorname{DOLS}(0,0) \mathrm{AIC}$ & $-0.104 *$ \\
\hline & $\operatorname{ARDL}(1,1) \mathrm{SIC}$ & & & ARDL $(1,1) \operatorname{SIC}$ & & & ARDL(1,1)FIX & $-0.132 *$ \\
\hline & YOY & $0.064 * * *$ & & YOY & 0.018 & & YOY & -0.064 \\
\hline \multirow{3}{*}{$\begin{array}{l}\text { EFF } \\
\text { VOL12 }\end{array}$} & $\operatorname{DOLS}(0,0) \mathrm{SIC}$ & $-0.039 * * *$ & $\mathrm{EFF}$ & $\operatorname{DOLS}(0,0) \mathrm{HQ}$ & $-0.051 * * *$ & EUR & $\operatorname{DOLS}(0,0) \mathrm{AIC}$ & $0.124 * * *$ \\
\hline & ARDL(1,1)FIX & & VOL12 & $\operatorname{ARDL}(1,1) \mathrm{SIC}$ & & VOL12 & $\operatorname{ARDL}(1,1) \mathrm{SIC}$ & \\
\hline & YOY & $-0.06^{* * *}$ & FDI12 & YOY & $-0.067 * *$ & FDI12 & YOY & $0.139 * * *$ \\
\hline \multirow{3}{*}{$\begin{array}{l}\text { EUR } \\
\text { VOL12 }\end{array}$} & $\operatorname{DOLS}(0,0) \mathrm{SIC}$ & $-0.025^{* * *}$ & EUR & $\operatorname{DOLS}(0,0)$ SIC & $-0.06^{* * *}$ & & & \\
\hline & $\operatorname{ARDL}(3,3) \mathrm{AIC}$ & $-0.033^{* *}$ & VOL12 & ARDL $(1,1) \mathrm{SIC}$ & & & & \\
\hline & YOY & $-0.071 * * *$ & FDI12 & YOY & $-0.121 * * *$ & & & \\
\hline
\end{tabular}

\section{DUM1}

\begin{tabular}{|c|c|c|c|c|c|c|c|c|}
\hline \multirow[t]{3}{*}{ EFF } & $\operatorname{DOLS}(0,0) \mathrm{SIC}$ & -0.016 & \multirow[t]{3}{*}{$\mathrm{EFF}$} & \multirow{2}{*}{\multicolumn{2}{|c|}{$\begin{array}{l}\operatorname{DOLS}(4,4) \mathrm{AIC} \\
\operatorname{ARDL}(1,1) \mathrm{SIC}\end{array}$}} & \multirow[t]{3}{*}{ EFF } & \multicolumn{2}{|c|}{$\operatorname{DOLS}(1,0)$ AIC $-0.166^{* * *}$} \\
\hline & $\operatorname{ARDL}(4,4) \mathrm{AIC}$ & -0.01 & & & & & \multicolumn{2}{|l|}{$\operatorname{ARDL}(1,1) \mathrm{SIC}$} \\
\hline & YOY & $0.134 * * *$ & & YOY & $-0.09 * * *$ & & YOY & $0.069^{* *}$ \\
\hline \multirow[t]{8}{*}{ EUR } & $\operatorname{DOLS}(0,0) \mathrm{SIC}$ & -0.005 & EUR & $\operatorname{DOLS}(4,4) \mathrm{AIC}$ & & EUR & $\operatorname{DOLS}(0,0) \mathrm{SIC}$ & $-0.179^{* * *}$ \\
\hline & $\operatorname{ARDL}(2,2) \mathrm{SIC}$ & & & $\operatorname{ARDL}(1,1) \mathrm{SIC}$ & & & $\operatorname{ARDL}(3,3) \mathrm{AIC}$ & $-0.197 * * *$ \\
\hline & YOY & 0.083 & & YOY & -0.018 & & YOY & 0.02 \\
\hline & & & $\mathrm{EFF}$ & $\operatorname{DOLS}(0,0)$ SIC & $-0.068 * * *$ & EUR & DOLS $(1,0)$ AIC & $-0.096^{*}$ \\
\hline & & & FDI12 & $\operatorname{ARDL}(1,1) \mathrm{SIC}$ & & VOL12 & $\operatorname{ARDL}(1,1) \operatorname{SIC}$ & \\
\hline & & & & YOY & $-0.087 * * *$ & FDI12 & YOY & $-0.108^{*}$ \\
\hline & & & EUR & $\operatorname{DOLS}(0,0)$ SIC & 0.021 & & & \\
\hline & & & FDI12 & $\operatorname{ARDL}(1,1) \mathrm{SIC}$ & $-0.059 *$ & & & \\
\hline
\end{tabular}

\section{DUM2}

\begin{tabular}{|c|c|c|c|c|c|c|c|c|}
\hline \multirow[t]{3}{*}{ EFF } & $\operatorname{DOLS}(0,0) \mathrm{SIC}$ & $-0.091^{*}$ & \multirow[t]{3}{*}{$\mathrm{EFF}$} & $\operatorname{DOLS}(0,0) \mathrm{SIC}$ & 0.044 & \multirow[t]{3}{*}{$\mathrm{EFF}$} & DOLS(1,1)AIC & $0.155^{* * *}$ \\
\hline & $\operatorname{ARDL}(4,4) \mathrm{AIC}$ & -0.098 & & \multicolumn{2}{|l|}{$\operatorname{ARDL}(1,1) \mathrm{SIC}$} & & \multicolumn{2}{|l|}{ ARDL $(1,1) \mathrm{SIC}$} \\
\hline & YOY & $0.063^{* *}$ & & YOY & $0.112 * * *$ & & YOY & $0.113^{* * *}$ \\
\hline \multirow[t]{6}{*}{ EUR } & $\operatorname{DOLS}(0,0)$ SIC & $-0.111^{*}$ & \multirow[t]{3}{*}{ EUR } & $\operatorname{DOLS}(0,0)$ SIC & & \multirow[t]{3}{*}{ EUR } & $\operatorname{DOLS}(0,4) \mathrm{AIC}$ & -0.136 \\
\hline & ARDL $(1,1) \mathrm{SIC}$ & -0.088 & & $\operatorname{ARDL}(1,1) \mathrm{SIC}$ & & & ARDL $(1,1)$ SIC & \\
\hline & YOY & $-0.135^{* * *}$ & & YOY & $0.059^{*}$ & & YOY & -0.013 \\
\hline & & & & & & \multirow{3}{*}{$\begin{array}{l}\text { EUR } \\
\text { FDI12 }\end{array}$} & $\operatorname{DOLS}(0,0)$ SIC & $0.207 * *$ \\
\hline & & & & & & & $\operatorname{ARDL}(1,1) \mathrm{SIC}$ & \\
\hline & & & & & & & YOY & 0.036 \\
\hline
\end{tabular}


Table 7e. Exchange Rate Volatility and Exports for Slovenia, Romania and Croatia

\begin{tabular}{|c|c|c|c|c|c|c|c|c|}
\hline \multicolumn{3}{|c|}{ Slovenia } & \multicolumn{3}{|c|}{ Romania } & \multicolumn{3}{|c|}{ Croatia } \\
\hline \multicolumn{9}{|c|}{ Real Exports } \\
\hline \multirow[t]{3}{*}{ EFF } & $\operatorname{DOLS}(0,0) \mathrm{SIC}$ & 0.032 & EFF & $\operatorname{DOLS}(0,4) \mathrm{SIC}$ & $-0.03 *$ & EFF & $\operatorname{DOLS}(4,1) \mathrm{AIC}$ & 0.172 \\
\hline & $\operatorname{ARDL}(3,3) \mathrm{SIC}$ & 0.02 & & $\operatorname{ARDL}(2,2) \mathrm{SIC}$ & & & ARDL $(1,1) \operatorname{SIC}$ & \\
\hline & YOY & 0.043 & & YOY & 0.000 & & YOY & $-0.346^{* *}$ \\
\hline \multirow[t]{9}{*}{ EUR } & $\operatorname{DOLS}(0,0) \mathrm{SIC}$ & 0.015 & EUR & $\operatorname{DOLS}(0,3)$ SIC & -0.017 & EUR & $\operatorname{DOLS}(0,0) \mathrm{SIC}$ & 0.028 \\
\hline & $\operatorname{ARDL}(3,3) \mathrm{SIC}$ & 0.016 & & $\operatorname{ARDL}(2,2) \mathrm{SIC}$ & & & $\operatorname{ARDL}(4,4) \mathrm{AIC}$ & 0.034 \\
\hline & YOY & -0.006 & & YOY & 0.006 & & YOY & 0.103 \\
\hline & & & EFF & $\operatorname{DOLS}(0,4) \mathrm{SIC}$ & & EUR & $\operatorname{DOLS}(4,1) \mathrm{SIC}$ & $-0.087^{*}$ \\
\hline & & & VOL12 & $\operatorname{ARDL}(2,2) \mathrm{SIC}$ & & & $\operatorname{ARDL}(4,4) \mathrm{FIX}$ & $-0.071 *$ \\
\hline & & & FDI12 & YOY & $-0.034 *$ & & YOY & $-0.134 *$ \\
\hline & & & EUR & $\operatorname{DOLS}(0,0) \mathrm{SIC}$ & & & & \\
\hline & & & VOL12 & $\operatorname{ARDL}(2,2) \operatorname{SIC}$ & & & & \\
\hline & & & FDI12 & YOY & $-0.041^{*}$ & & & \\
\hline
\end{tabular}

Nominal Exports

\begin{tabular}{|c|c|c|c|c|c|c|c|c|}
\hline \multirow[t]{3}{*}{ EFF } & $\operatorname{DOLS}(0,0) \operatorname{SIC}$ & -0.004 & $\mathrm{EFF}$ & $\operatorname{DOLS}(0,1) \operatorname{SIC}$ & -0.019 & $\mathrm{EFF}$ & $\operatorname{DOLS}(0,0) \mathrm{SIC}$ & -0.057 \\
\hline & $\operatorname{ARDL}(3,3) \mathrm{SIC}$ & 0.014 & & \multicolumn{2}{|l|}{$\operatorname{ARDL}(2,2) \mathrm{SIC}$} & & \multicolumn{2}{|l|}{$\operatorname{ARDL}(1,1) \mathrm{SIC}$} \\
\hline & YOY & 0.033 & & YOY & 0.004 & & YOY & $-0.458 * * *$ \\
\hline EUR & $\operatorname{DOLS}(0,0)$ SIC & $-0.052^{*}$ & EUR & $\operatorname{DOLS}(3,4) \mathrm{AIC}$ & 0.012 & EUR & $\operatorname{DOLS}(3,3) \mathrm{AIC}$ & 0.035 \\
\hline VOL12 & $\operatorname{ARDL}(1,1) \mathrm{SIC}$ & -0.058 & & $\operatorname{ARDL}(1,1) \mathrm{SIC}$ & & & $\operatorname{ARDL}(2,2) \mathrm{SIC}$ & \\
\hline \multirow[t]{4}{*}{ FDI12 } & YOY & -0.008 & & YOY & 0.061 & & YOY & 0.090 \\
\hline & & & & & & EFF & $\operatorname{DOLS}(0,0) \mathrm{SIC}$ & $0.124 *$ \\
\hline & & & & & & VOL12 & $\operatorname{ARDL}(1,1) \mathrm{SIC}$ & \\
\hline & & & & & & FDI12 & YOY & 0.1 \\
\hline \multirow[t]{2}{*}{ EUR } & & & EUR & & & EUR & $\operatorname{DOLS}(1,0) \mathrm{AIC}$ & $-0.083 * *$ \\
\hline & & & & & & VOL12 & $\operatorname{ARDL}(2,2) \mathrm{AIC}$ & $-0.125^{* * *}$ \\
\hline FDI12 & YOY & $-0.21 * * *$ & FDI12 & YOY & $-0.21 * * *$ & FDI12 & YOY & $-0.21 * * *$ \\
\hline
\end{tabular}

Notes: As for table 7a. 


\section{Concluding Remarks}

In this paper, we made an attempt to provide answers to the questions of whether changes in exchange rate regimes and exchange rate volatility have any impact on the exports of transition economies.

The countries under study can be divided into two broad groups reflecting the evolution of exchange rate regimes over time. One group of countries, including the Czech Republic, Hungary, Poland and Slovakia, started transition with pegged regimes and then moved, at different paces, toward more flexibility. Bulgaria first had a managed float and then switched to a currency board in 1997. Russia and Ukraine experienced cyclical movements from flexibility to more rigid regimes and then back again to more flexibility. The second group, containing Croatia, Romania and Slovenia, have experienced no changes in their exchange rate regimes for the last ten years or so.

Both the direct impact of forex volatility and the indirect impact via changes in the exchange rate regime were assessed on the basis of standard export equations, augmented with FDI, which captures the very essence of economic transformation. The estimation results for panels, including ten and eight transition economies, suggest that a rise in forex volatility measured either directly or via changes in the exchange rate regime weakens exports to some extent, and that this negative impact is transmitted with some delay rather than being instantaneous. A meticulous look at sectoral exports confirms this finding in the sectors chemicals and different types of manufacturing. These sectors, together providing up to $80 \%$ of total exports, are found to suffer from increased exchange rate volatility.

More country-specific insights can be gained from time series estimations based on cointegration and using year-on-year changes in the variables. The results range from one end of the spectrum to the other. For some countries, such as Slovenia and Russia, there is little evidence in favor of a negative relation between forex volatility and exports. This outcome is not surprising in view of the low observed volatility of the Slovenian tolar, as the Bank of Slovenia was trying to target not only the level but also the volatility of the exchange rate. An explanation for Russia's insensitivity toward forex volatility might be the high share of oil-related products in total exports (close to 50\%), the demand for which depends more on the level of the exchange rate than on its variance. There is some weak evidence 
for Romania. Croatia, the Czech Republic, Hungary and Poland are located at the other end of the spectrum; for these countries, the estimation results provide some evidence on the detrimental effect of forex volatility on exports. Although the results are sensitive to the use of real and nominal variables and to different estimation methods, some general conclusions may be drawn bearing these caveats in mind. While exchange rate volatility seems to have an instantaneous effect on exports in the Czech case, it feeds into poor export performance only with some delay in the three other countries. Regarding shifts in the exchange rate regime, more specifically a move toward more flexibility, it appears that the recent period of widening of the fluctuation bands to $\pm 15 \%$ in Hungary can be associated with a fall in exports, conditioned, of course, on the other variables, such as foreign and domestic output, prices, the level of the exchange rate and FDI. For Poland and Slovakia, what we can observe is that the onset of more exchange rate flexibility is accompanied by a drop in exports, but exports seem to have recovered later on.

To summarize, we did not embark on this enterprise in vain, as we found convincing evidence that exchange rate volatility might impact negatively on export flows in the CEE transition economies. Hence, our project turns out to be not just another blur project. We also found that key exporting sectors, namely manufacturing, might be badly affected by exchange rate volatility. Nonetheless, countryspecific results also showed that some countries are concerned to a large extent whereas others seem to be spared the toxic effect of exchange rate volatility. However, the countries with the largest share of manufacturing goods in total exports, such as the Czech Republic and Hungary, are found to be more likely to be exposed to exchange rate volatility than the others. Another reason for the higher vulnerability of these countries to forex volatility might be their large share of intraindustry trade in total trade, and in particular in manufacturing (Fontaigné and Freudenberg, 1999). ${ }^{16}$ Furthermore, this negative impact might be related to more exchange rate flexibility for some countries. This may be another important motivation for the new EU Member States, especially for Hungary, and perhaps to a lesser extent for the Czech Republic and Poland to aim at achieving more exchange rate stability.

$1 \overline{\text { See Fidrmuc and Korhonen (2004) }}$ for the share of intraindustry trade in total trade of the countries under study. 


\section{References}

Achy, L. and K. Sekkat. 2001. The European Single Currency and MENA's Export to Europe. Manuscript.

Andrews, D. 1993. Test for Parameter Instability and Structural Change with Unknown Change Point. In: Econometrica 61. 821-856.

Andrews, D. and W. Ploberger. 1994. Optimal Tests When a Nuisance Parameter is Present Only Under the Alternative. In: Econometrica 62. 1383-1414.

Aristotelous, K. 2001. Exchange-Rate Volatility, Exchange-Rate Regime and Trade Volume: Evidence from the UK-US Export Function. 1889-1999). In: Economics Letters 72. 87-94.

Arize, A.C., T. Osang and D.J. Slottje. 2004. Exchange Rate Volatility in Latin American and its Impact on Foreign Trade. Manuscript.

Baak, S. 2004. Exchange Rate Volatility and Trade among the Asian Pacific Countries. Manuscript.

Babetskaia-Kukharchuk, O. and M. Maurel. 2004. Russia's accession to the WTO: the potential for trade increase. In: Journal of Comparative Economics 32(4). 680-699.

Babetskii I., O. Babetskaia-Kukharchuk and M. Raiser. 2003. How deep is your trade? Transition and international integration in eastern Europe and the former Soviet Union. EBRD Working Paper 83. November.

Banerjee, A., M. Marcellino and C. Osbat. 2004. Some Cautions on the Use of Panel Methods for Integrated Series of Macroeconomic Data. In: Econometrics Journal 7(2). 322-340.

Barrell, R. and D. Holland. 2000. Foreign Direct Investment and Enterprise Restructuring in Central Europe. In: Economics of Transition 8(2). 477-504.

Benáček, V., L. Prokop and J. Á. Víšek. 2003. Determining Factors of the Czech Foreign Trade Balance: Structural Issues in Trade Creation. ČNB Working Paper 3.

Bini-Smaghi, L. 1991. Exchange Rate Variability and Trade: Why Is It So Difficult to Find Any Relationship? In: Applied Economics 23. 927-936.

Bussière, M., J. Fidrmuc and B. Schnatz. 2004. Trade Integration of the New EU Member States 
and Selected South Eastern European Countries: Lessons from a Gravity Model. Paper presented at the Conference on European Economic Integration. November 28 to 30, 2004, Vienna.

Camacho, M. 2004. Vector Smooth Transition Regression Models for the US GDP and the Composite Index of Leading Indicators. In: Journal of Forecasting 23. 173-196.

Campos, M. and Y. Kinoshita. 2002. Foreign direct investment as technology transferred: Some panel evidence from the transition economies. In: The Manchester School 70(3). 398-419.

Chou, W. L. 2000. Exchange Rate Variability and China's Exports. In: Journal of Comparative Economics 28. 61-79.

Doroodian, K. 1999. Does Exchange Rate Volatility Deter International Trade in Developing Countries. In: Journal of Asian Economics 10. 465-474.

Fidrmuc, J. and I. Korhonen. 2004. A meta-analysis of business cycle correlation between the euro area and CEECs: What do we know - and who cares? BOFIT Dicussion Paper 20.

Fontaigné, L. G. and M. Freudenberg. 1999. Endogenous Symmetry of Shocks in a Monetary Union. In: Open Economies Review 10(3). 263-287.

Fountas, S. and K. Aristotelous. 1999. Has the European Monetary System Led to More Exports? Evidence from Four European Union Countries. In: Economics Letters 62. 357-363.

Frankel, J. and A. Rose 2002. An Estimate of the Effect of Common Currencies on Trade and Income. In: The Quarterly Journal of Economics 117(2). 437-466.

Hansen, B.E. 1997. Approximate Asymptotic P Values for Structural-Change Tests. In: Journal of Business and Economic Statistics 15. 60-67.

Im, K-S., M. H. Pesaran and Y. Shin. 2003. Testing for Unit Roots in Heterogeneous Panels . In: Journal of Econometrics 115. 53-74.

Inclán, C. and G. C. Tiao. 1994. Use of Cumulative Sums of Squares for Retrospective Detection of Changes of Variance. In: Journal of American Statistical Association 89. 913-923.

Klein, M. W. 1990. Sectoral Effects of Exchange Rate Volatility on United States Exports. In: Journal of International Money and Finance 9. 229-308. 
McConnell, M. M. and G. Pérez-Quirós. 2000. Output Fluctuations in the United States: What has Changed Since the Early 1980s?. American Economic Review 90. 1464-1476.

McKenzie, M.D. 1999. The Impact of Exchange Rate Volatility on International Trade Flows. In: Journal of Economic Surveys 13. 71-106.

McKenzie, M. D. 1998. The Impact of Exchange Rate Volatility on Australian Trade Flows. Journal of International Financial Markets. In: Institutions and Money 8. 21-38.

Pedroni, P. 1999. Critical Values for Cointegration Tests in Heterogeneous Panels with Multiple Regressors. In: Oxford Bulletin of Economics and Statistics 61. 653-670.

Pesaran, M. H., Y. Shin and R. J. Smith. 2001. Bounds testing approaches to the analysis of level relationships. In: Journal of Applied Econometrics 16(3). 289-326.

Rose, A. 2000. One Money, One Market: Estimating the Effect of Common Currency on Trade. In: Economic Policy 30. 7-45.

Siregar, R. and R. S. Rajan. 2002. Impact of Exchange Rate Volatility on Indonesia's Trade Performance in the 1990s. Centre for International Economic Studies Discussion Paper 0205.

Stock, J. H. and M. W. Watson. 1993. A Simple Estimator of Cointegrating Vectors in Higher Order Integrated Systems. Econometrica 61(4). 783-820.

Taglioni, D. 2002. Exchange Rate Volatility as a Barrier to Trade: New Methodologies and Recent Evidence. In: Economie Internationale 89-90(1). 227-259.

Tenreyro, S. 2003. On the Trade Impact of Nominal Exchange Rate Volatility. Federal Reserve Bank of Boston Working Paper 32.

Wei, S. J. 1998. Currency Hedging and Goods Trade. National Bureau of Economic Research Working Paper 6742. 


\section{DAVIDSON INSTITUTE WORKING PAPER SERIES - Most Recent Papers}

The entire Working Paper Series may be downloaded free of charge at: www.wdi.bus.umich.edu

CURRENT AS OF 7/13/05

\begin{tabular}{|c|c|c|}
\hline Publication & Authors & Date \\
\hline $\begin{array}{l}\text { No. 782: Exchange Rate Regimes, Foreign Exchange Volatility and } \\
\text { Export Performance in Central and Eastern Europe: Just Another Blur } \\
\text { Project? }\end{array}$ & $\begin{array}{l}\text { Balázs Égert and Amalia } \\
\text { Morales-Zumaquero }\end{array}$ & July 2005 \\
\hline $\begin{array}{l}\text { No. 781: Equilibrium Exchange Rate in the Czech Republic: How Good } \\
\text { is the Czech BEER? }\end{array}$ & Ian Babetskii and Balázs Égert & July 2005 \\
\hline $\begin{array}{l}\text { No. 780: Autonomy and Performance of Foreign Subsidiaries in five } \\
\text { Transition Countries }\end{array}$ & $\begin{array}{l}\text { Urmas Varblane, Katrin Männik, } \\
\text { and Helena Hannula }\end{array}$ & July 2005 \\
\hline $\begin{array}{l}\text { No. 779: The Political Economy of Industrial Policy in China: The Case } \\
\text { of Aircraft Manufacturing }\end{array}$ & Andrea Goldstein & July 2005 \\
\hline $\begin{array}{l}\text { No. 778: Bank Supervision Russian style: Rules versus Enforcement } \\
\text { and Tacit Objectives }\end{array}$ & $\begin{array}{l}\text { Sophie Claeys, Gleb Lanine and } \\
\text { Koen Schoors }\end{array}$ & June 2005 \\
\hline No. 777: Labor Market Trends and Institutions in Belarus & $\begin{array}{l}\text { Zuzana Brixiova and Vera } \\
\text { Volchok }\end{array}$ & June 2005 \\
\hline $\begin{array}{l}\text { No. 776: Can Vietnam Achieve One of its Millennium Development } \\
\text { Goals? An analysis of schooling dropouts of children }\end{array}$ & $\begin{array}{l}\text { Vo Tri Thanh And Trinh Quang } \\
\text { Long }\end{array}$ & June 2005 \\
\hline $\begin{array}{l}\text { No. 775: Is The Link Between Reforms And Growth Spurious? A } \\
\text { Comment }\end{array}$ & Tomasz Mickiewicz & May 2005 \\
\hline $\begin{array}{l}\text { No. 774: The Risk Aversion of Banks in Emerging Credit markets: } \\
\text { Evidence from India }\end{array}$ & $\begin{array}{l}\text { Sumon Kumar Bhaumik and } \\
\text { Jenifer Piesse }\end{array}$ & May 2005 \\
\hline $\begin{array}{l}\text { No. 773: Organized Labor and Restructuring: Coal Mines in the Czech } \\
\text { Republic and Romania }\end{array}$ & $\begin{array}{l}\text { Jan Bruha, Delia Ionascu, and } \\
\text { Byeongju Jeong }\end{array}$ & May 2005 \\
\hline $\begin{array}{l}\text { No. 772: Is Political Risk Company-Specific? The Market Side of the } \\
\text { Yukos Affair }\end{array}$ & $\begin{array}{l}\text { Alexei Goriaev and Konstantin } \\
\text { Sonin }\end{array}$ & May 2005 \\
\hline $\begin{array}{l}\text { No. 771: Non-Linear Exchange Rate Dynamics in Target Zones: A } \\
\text { Bumpy Road Towards A Honeymoon }\end{array}$ & $\begin{array}{l}\text { Jesús Crespo-Cuaresma, Balázs } \\
\text { Égert, and Ronald MacDonald }\end{array}$ & May 2005 \\
\hline $\begin{array}{l}\text { No. 770: Equilibrium Exchange Rates in Southeastern Europe, Russia, } \\
\text { Ukraine and Turkey: Healthy or (Dutch) Diseased? }\end{array}$ & Balázs Égert & May 2005 \\
\hline $\begin{array}{l}\text { No. 769: Equilibrium Exchange Rates in Central and Eastern Europe: A } \\
\text { Meta-Regression Analysis }\end{array}$ & Balázs Égert and László Halpern & May 2005 \\
\hline $\begin{array}{l}\text { No. 768: Testing for inflation convergence between the Euro Zone } \\
\text { and its CEE partners }\end{array}$ & Imed Drine and Christophe Rault & Apr. 2005 \\
\hline $\begin{array}{l}\text { No. 767: Labor Mobility during Transition: Evidence from the Czech } \\
\text { Republic }\end{array}$ & Jan Fidrmuc & Apr. 2005 \\
\hline $\begin{array}{l}\text { No. 766: Formation of social capital in Central and Eastern Europe: } \\
\text { Understanding the gap vis-à-vis developed countries }\end{array}$ & Jan Fidrmuc and Klarita Gërxhani & Apr. 2005 \\
\hline $\begin{array}{l}\text { No. 765: Do Regional Integration Agreements Increase Business-Cycle } \\
\text { Convergence? Evidence From APEC and NAFTA }\end{array}$ & $\begin{array}{l}\text { Viviana Fernandez and Ali M. } \\
\text { Kutan }\end{array}$ & Apr. 2005 \\
\hline $\begin{array}{l}\text { No. 764: State Regulations, Job Search and Wage Bargaining: A Study } \\
\text { in the Economics of the Informal Sector }\end{array}$ & Maxim Bouev & Apr. 2005 \\
\hline $\begin{array}{l}\text { No. 763: The Feldstein-Horioka Puzzle Revisited: An “European- } \\
\text { Regional” Perspective }\end{array}$ & $\begin{array}{l}\text { Jérôme Hericourt and Mathilde } \\
\text { Maurel }\end{array}$ & Apr. 2005 \\
\hline $\begin{array}{l}\text { No. 762: Transatlantic Differences in Labour Markets Changes in Wage } \\
\text { and Non-Employment Structures in the 1980s and the 1990s }\end{array}$ & Patrick A. Puhani & Mar. 2005 \\
\hline $\begin{array}{l}\text { No. 761: Resolution, Recovery and Survival: The Evolution of Payment } \\
\text { Disputes in Post-Socialist Europe }\end{array}$ & William Pyle & Mar. 2005 \\
\hline $\begin{array}{l}\text { No. 760: Official Foreign Exchange Interventions in the Czech } \\
\text { Republic: Did They Matter? }\end{array}$ & Balázs Égert and Luboš Komárek & Mar. 2005 \\
\hline $\begin{array}{l}\text { No. 759: Assessing Market Expectations on Exchange Rates and } \\
\text { Inflation: A Pilot Forecasting System for Bulgaria }\end{array}$ & $\begin{array}{l}\text { Michael Berlemann, Kalina } \\
\text { Dimitrova, \& Nikolay Nenovsky }\end{array}$ & Mar. 2005 \\
\hline No. 758: Attitudes and Performance: An Analysis of Russian Workers & $\begin{array}{l}\text { Susan J. Linz and Anastasia } \\
\text { Semykina }\end{array}$ & Mar. 2005 \\
\hline $\begin{array}{l}\text { No. 757: Barter, Credit, and Welfare: A theoretical inquiry into the } \\
\text { barter phenomenon in Russia }\end{array}$ & José Noguera and Susan J. Linz & Mar. 2005 \\
\hline
\end{tabular}

